\title{
Biodegradation of phenanthrene by Pseudomonas sp. strain PPD: purification and characterization of 1-hydroxy-2-naphthoic acid dioxygenase
}

Correspondence

Prashant S. Phale

pphale@uitb.ac.in

Received 28 April 2009

Revised 27 June 2009

Accepted 1 July 2009
Jaigeeth Deveryshetty and Prashant S. Phale

\author{
Biotechnology Group, Department of Biosciences and Bioengineering, Indian Institute of \\ Technology - Bombay, Powai, Mumbai 400 076, India
}

\section{INTRODUCTION}

Phenanthrene, a major pollutant, is the smallest polycyclic aromatic hydrocarbon to have a 'bay-region' and a 'Kregion'. The epoxides formed at the bay- and K-region are highly reactive as compared to the parent compound and are suspected carcinogens (Bucker et al., 1979; Mastrangelo et al., 1996). Therefore phenanthrene is often used as a model substrate to study the metabolism of polycyclic aromatic hydrocarbons.

Several bacterial species capable of degrading phenanthrene have been reported (Phale et al., 2007). The metabolic pathway is initiated by a ring-hydroxylating dioxygenase to yield cis-3,4-dihydroxy-3,4-dihydrophenanthrene, which is subsequently metabolized to 1-hydroxy-2-naphthoic acid (1-H2NA). The 1-H2NA generated is metabolized by one of two distinct routes, the 'phthalic acid' or the 'naphthalene' route (Fig. 1). In the 'phthalic acid' route, 1-H2NA is cleaved by 1-hydroxy-2-naphthoic acid dioxygenase (1-HNDO; EC 1.13.11.38) to yield 2-carboxyben-

Abbreviations: 2-CBADH, 2-carboxybenzaldehyde dehydrogenase; GDO, gentisic acid 1,2-dioxygenase; 2-H1NA, 2-hydroxy-1-naphthoic acid; 1-H2NA, 1-hydroxy-2-naphthoic acid; 3-H2NA, 3-hydroxy-2naphthoic acid; 6-H2NA, 6-hydroxy-2-naphthoic acid; 1-HNDO, 1hydroxy-2-naphthoic acid dioxygenase; P3,4DO, protocatechuate 3,4dioxygenase; P4,5DO, protocatechuic acid 4,5-dioxygenase; SDO, salicylic acid 1,2-dioxygenase. zalpyruvic acid, which is further metabolized via phthalic acid to tricarboxylic acid cycle intermediates (Kiyohara et al., 1976). In the 'naphthalene' route, 1-H2NA is metabolized via 1,2-dihydroxynaphthalene and salicylic acid (Evans et al., 1965). Further, alternative routes exist which metabolize 1-H2NA via 1-naphthol (Prabhu \& Phale, 2003; Samanta et al., 1999).

Ring-cleaving dioxygenases play an important role in the degradation of aromatic compounds; they catalyse the incorporation of two atoms of molecular oxygen into substrates. Based on the mode of ring-cleavage, they are grouped as (a) extradiol dioxygenases, which require nonhaem $\mathrm{Fe}(\mathrm{II})$ and cleave the aromatic ring proximal to one of the two hydroxylated carbon atoms, yielding a semialdehyde (Kojima et al., 1961); and (b) intradiol dioxygenases, which require non-haem $\mathrm{Fe}(\mathrm{III})$ and cleave the aromatic ring between the two hydroxylated carbon atoms, yielding a muconic acid (Hayaishi \& Hoshimoto, 1950). Both groups of enzymes have been studied extensively (Arciero \& Lipscomb, 1986; Davis et al., 2002; Kita et al., 1999; Shu et al., 1995; Vetting et al., 2000; Vetting \& Ohlendorf, 2000). The ring-cleavage of gentisic acid, homogentisic acid, salicylic acid and 1-H2NA is distinct from that catalysed by intradiol and extradiol ringcleaving dioxygenases (Adachi et al., 1999; Adams et al., 2006; Barnsley, 1983; Crawford et al., 1975; Feng et al., 1999; Harpel \& Lipscomb, 1990; Hintner et al., 2004; 


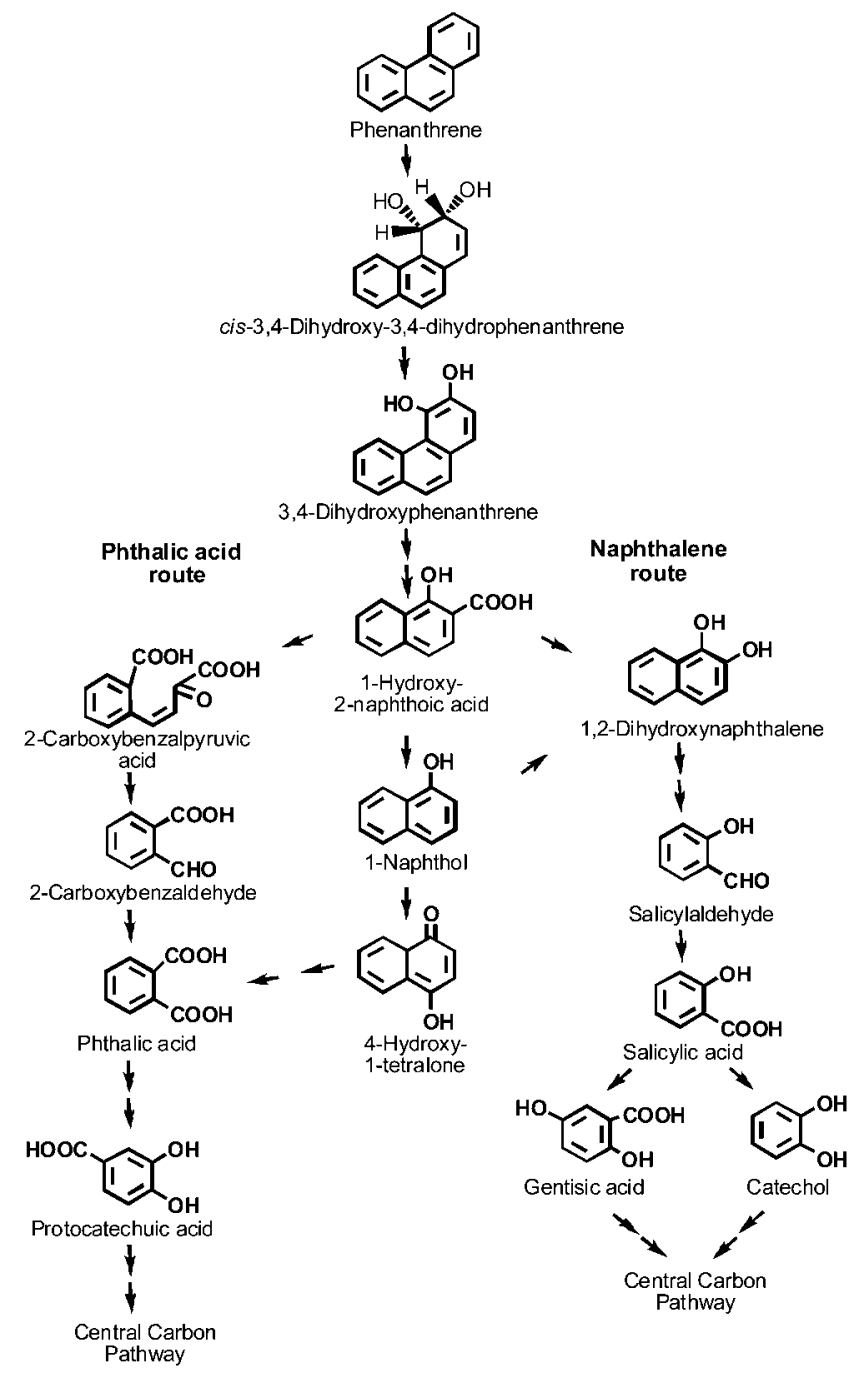

Fig. 1. Metabolic pathways for the degradation of phenanthrene in bacteria: Aeromonas, Alcaligenes, Bacillus and Micrococcus sp. degrade 1-H2NA via the 'phthalic acid' pathway (Doddamani \& Ninnekar, 2000; Ghosh \& Misra, 1983; Kiyohara et al., 1976) while Pseudomonas spp. metabolize 1-H2NA via the 'naphthalene' pathway (Evans et al., 1965). Diversity in the metabolism is generated by degrading phenanthrene via 1-naphthol (Prabhu \& Phale, 2003; Samanta et al., 1999).

Iwabuchi \& Harayama, 1998; Matera et al., 2008). So far there are only two reports on 1-HNDO, from Gramnegative bacterium strain B156 and Nocardioides sp. strain KP7 (Barnsley, 1983; Iwabuchi \& Harayama, 1998). Pseudomonas sp. strain PPD can utilize phenanthrene, hydroxybenzoic acids ( $o-, m$ - and $p$-) and phthalic acid isomers $\left(o-, m\right.$ - and $\left.p^{-}\right)$as the sole source of carbon and energy (Deveryshetty et al., 2007; Vamsee-Krishna et al., 2006). Here, we report the metabolic pathway for degradation of phenanthrene in Pseudomonas sp. strain PPD, and the affinity purification and characterization of 1-HNDO from this bacterium.

\section{METHODS}

Chemicals. Phenanthrene, 1-H2NA, salicylic acid, gentisic acid, 3hydroxy-2-naphthoic acid (3-H2NA), 2-hydroxy-1-naphthoic acid (2-H1NA), 6-hydroxy-2-naphthoic acid (6-H2NA), 1-naphthol, 2naphthol, 1-naphthoic acid, 2-naphthoic acid, 3-hydroxybenzoic acid, 4-hydroxybenzoic acid, 1,2-dihydroxynaphthalene, catechol, protocatechuic acid, EGTA, EDTA, 1,10-phenanthroline, 2,2'-dipyridyl, Sepharose CL-4B, DEAE-Sephacel, Sephacryl S-200-HR and benzidine were purchased from Sigma-Aldrich. All other chemicals used were of analytical grade and purchased locally.

Bacterial culture and growth conditions. Pseudomonas sp. strain PPD, originally isolated from soil, was grown in $150 \mathrm{ml}$ minimal salt medium (MSM) plus phenanthrene $(0.1 \%)$ or glucose $(0.25 \%)$ in $500 \mathrm{ml}$ baffled Erlenmeyer flasks at $30{ }^{\circ} \mathrm{C}$ on a rotary shaker at 200 r.p.m. (Vamsee-Krishna et al., 2006).

Whole-cell oxygen uptake. Cells grown on appropriate carbon sources were used to monitor whole-cell $\mathrm{O}_{2}$ uptake. Rates were measured in the presence of various probable metabolic intermediates at $30{ }^{\circ} \mathrm{C}$ using an oxygraph (Hansatech) fitted with a Clark-type electrode as described previously (Deveryshetty et al., 2007).

Preparation of cell-free extract and enzyme assays. Cells were harvested by centrifugation, washed twice with Tris/ $\mathrm{HCl}(50 \mathrm{mM}$, $\mathrm{pH} 7.5$ ), and cell-free extract was prepared as described previously (Deveryshetty et al., 2007).

1-HNDO activity was monitored spectrophotometrically (Perkin Elmer Lambda 35) by measuring the rate of product formation as the increase in absorbance at $300 \mathrm{~nm}$. The reaction mixture $(1 \mathrm{ml})$ contained 1-H2NA $(100 \mu \mathrm{M})$, an appropriate amount of enzyme and Tris/ $\mathrm{HCl}$ buffer $(50 \mathrm{mM}, \mathrm{pH} 7.5)$. Enzyme activity of 1-HNDO was calculated using an absorption coefficient difference of $11.5 \mathrm{mM}^{-1}$ $\mathrm{cm}^{-1}$ between 2-carboxybenzalpyruvic acid and 1-H2NA as described by Iwabuchi \& Harayama (1998). Phthalic acid dioxygenaseoxygenase and -reductase component (Vamsee-Krishna et al., 2006), catechol 2,3-dioxygenase (Kojima et al., 1961), catechol 1,2dioxygenase (Hayaishi \& Hoshimoto, 1950), gentisic acid dioxygenase (Harpel \& Lipscomb, 1990), 2-carboxybenzaldehyde dehydrogenase (Iwabuchi \& Harayama, 1997), and protocatechuic acid 3,4- and 4,5dioxygenase (Ono et al., 1970; Stanier \& Ingraham, 1954) were monitored as described in the references cited. Enzyme activities were expressed as units (nanomoles or $\mu$ moles of product formed or substrate disappeared, NADH formed or $\mathrm{O}_{2}$ consumed) $\mathrm{min}^{-1} \mathrm{ml}^{-1}$. Specific activities were expressed as units $(\mathrm{mg} \text { protein })^{-1}$. Protein concentration was determined by the method of Bradford (1976), using bovine serum albumin (BSA) as standard.

Identification of metabolites from biotransformation and bulk enzyme reactions. Biotransformations were carried out with cells grown on phenanthrene to the late-exponential phase. Cells were harvested, washed twice with Tris/ $\mathrm{HCl}$ buffer $(50 \mathrm{mM}, \mathrm{pH} 7.5)$, resuspended in MSM ( $200 \mathrm{mg}$ wet weight cells in $80 \mathrm{ml})$ containing the desired compound $(0.1 \%)$ and incubated at $30{ }^{\circ} \mathrm{C}$ for $4 \mathrm{~h}$ on a rotary shaker. After separating cells, spent medium was acidified to $\mathrm{pH} 2$ (with $1 \mathrm{M} \mathrm{HCl}$ ) and extracted with an equal volume of ethyl acetate. The organic phase was dried over anhydrous sodium sulfate and concentrated. The reaction products were resolved by TLC on silica gel $\mathrm{G}$, using the solvent system hexane/chloroform/acetic acid ( $7: 3: 1$, by vol.) and identified by comparing $R_{\mathrm{f}}$ and UV-fluorescence properties at $254 \mathrm{~nm}$ with those of authentic compounds.

To identify the enzyme reaction products, bulk enzyme reactions $(15 \mathrm{ml})$ were performed for 1-HNDO in mixtures which contained Tris/HCl buffer $(50 \mathrm{mM}, \mathrm{pH} 7.5), \mathrm{NAD}^{+}(200 \mu \mathrm{M}), \quad 1-\mathrm{H} 2 \mathrm{NA}$ $(200 \mu \mathrm{M})$ and an appropriate amount of cell-free extract or purified 
1-HNDO. The reaction was carried out at $30{ }^{\circ} \mathrm{C}$ for $80 \mathrm{~min}$ with addition of $\mathrm{NAD}^{+}$every $20 \mathrm{~min}$. The reaction mixture for 2carboxybenzaldehyde dehydrogenase (2-CBADH) contained glycine/ $\mathrm{KOH}$ buffer $(50 \mathrm{mM}, \mathrm{pH} 9.6), \mathrm{NAD}^{+}(200 \mu \mathrm{M})$, 2-carboxybenzaldehyde $(200 \mu \mathrm{M})$ and an appropriate amount of cell-free extract. Control reactions contained all components except substrate or enzyme. The reaction was terminated by adjusting the $\mathrm{pH}$ to 2 , and the reaction products were extracted and analysed by TLC as described above.

\section{Purification of 1-HNDO from Pseudomonas sp. strain PPD}

1-HNDO was purified to homogeneity using following steps. All the steps were carried out at $4{ }^{\circ} \mathrm{C}$ or on ice.

(i) Preparation of cell-free extract. Cells grown on phenanthrene were harvested and washed twice with buffer 1 [MOPS $(50 \mathrm{mM}$, $\mathrm{pH} 7.5)$, glycerol $(5 \%, \mathrm{v} / \mathrm{v}), \mathrm{Fe}\left(\mathrm{NH}_{4}\right)_{2}\left(\mathrm{SO}_{4}\right)_{2}(0.1 \mathrm{mM})$ and DTT $(2 \mathrm{mM})]$. The cells were suspended in ice-cold buffer $1(\sim 1.8 \mathrm{~g}$ in $8 \mathrm{ml}$ ) and sonicated using an ultrasonic processor (GE130) on ice, with 10 cycles of 20 pulses each ( $1 \mathrm{~s}$ pulse, $1 \mathrm{~s}$ interval, cycle duration $40 \mathrm{~s}$, output of $20 \mathrm{~W}, 3$ min interval between two cycles). The supernatant obtained after centrifuging cell homogenate at $50000 \mathrm{~g}$ for $30 \mathrm{~min}$ was referred to as the cell-free extract.

(ii) Heat treatment. The cell-free extract was incubated at $60{ }^{\circ} \mathrm{C}$ in a water bath in the presence of 3-H2NA $(1 \mathrm{mM})$ with intermittent shaking. After $20 \mathrm{~min}$ incubation, the extract was immediately transferred on to ice. Denatured proteins were removed by centrifugation at $35000 \mathrm{~g}$ for $30 \mathrm{~min}$. Supernatant was dialysed against buffer 2 [MOPS buffer $(50 \mathrm{mM}, \mathrm{pH} 7.5)$ containing $\mathrm{Fe}\left(\mathrm{NH}_{4}\right)_{2}\left(\mathrm{SO}_{4}\right)_{2} \quad(0.1 \mathrm{mM})$, DTT $(2 \mathrm{mM})$, glycerol $(5 \%)$ and ethanol $(10 \%)$ ] and processed further.

(iii) 3-H2NA-affinity chromatography. The affinity matrix was prepared using $3-\mathrm{H} 2 \mathrm{NA}$ as a ligand. Sepharose CL-4B was activated by $\mathrm{CNBr}$ as described by March et al. (1974). CNBr-activated Sepharose CL-4B was converted to benzidyl Sepharose CL-4B and coupled to $3-\mathrm{H} 2 \mathrm{NA}$ as described by Sugumaran \& Vaidyanathan (1978). The purple-coloured matrix obtained was washed with $750 \mathrm{ml} \mathrm{HCl}(0.1 \mathrm{M}), 11 \mathrm{Tris} /$ maleate $(25 \mathrm{mM}, \mathrm{pH} 6.0)$ and 11 distilled water. The matrix was suspended in distilled water and used for affinity purification.

The extract obtained from step (ii) was loaded onto the 3-H2NAaffinity column (bed vol. $43 \mathrm{ml} ; 18 \times 200 \mathrm{~mm}$ ) pre-equilibrated with buffer 2 at the rate of $6 \mathrm{ml} \mathrm{h}^{-1}$. The column was washed with buffer 2 $(150 \mathrm{ml})$ and eluted with a linear gradient of $3-\mathrm{H} 2 \mathrm{NA}(0-5 \mathrm{mM}$, $200 \mathrm{ml}$ ) at a flow rate of $30 \mathrm{ml} \mathrm{h}^{-1}$.

(iv) DEAE-anion-exchange chromatography. Fractions from 3H2NA-affinity chromatography containing 1-HNDO activity $\left(>1 \mu \mathrm{mol} \mathrm{min} \mathrm{ml}^{-1}\right)$ were pooled and loaded onto a DEAESephacel column (bed vol. $19 \mathrm{ml} ; 18 \times 100 \mathrm{~mm}$ ) equilibrated with buffer 2 . The column was washed extensively with the same buffer and eluted with a linear gradient of $\mathrm{KCl}(0-0.4 \mathrm{M}, 100 \mathrm{ml})$ at flow rate of $30 \mathrm{ml} \mathrm{h}^{-1}$. Active fractions from the DEAE column were pooled and dialysed (12 kDa cut-off) against MOPS buffer $(50 \mathrm{mM}$, pH 7.5) containing $\left(\mathrm{NH}_{4}\right)_{2} \mathrm{Fe}\left(\mathrm{SO}_{4}\right)_{2}(0.1 \mathrm{mM})$, DTT $(2 \mathrm{mM})$ and glycerol $(40 \%)$ for $3 \mathrm{~h}$ and stored at $-20{ }^{\circ} \mathrm{C}$ until further use.

Determination of molecular mass. The subunit molecular mass was determined by $12 \%$ SDS-PAGE under denaturing conditions (Laemmli, 1970). The native molecular mass was determined by Sephacryl S-200-HR gel-filtration chromatography. The column (bed $170 \mathrm{ml}$; void $55 \mathrm{ml} ; 16 \times 860 \mathrm{~mm}$, flow rate $3.5 \mathrm{ml} \mathrm{h}^{-1}$ ) was equilibrated with Tris/HCl buffer $(50 \mathrm{mM}, \mathrm{pH} 7.5)$ containing glycerol (5\%) and ethanol (10\%) and calibrated with standard protein markers.

\section{RESULTS}

\section{Metabolism of phenanthrene by Pseudomonas sp. strain PPD}

Culture grown on phenanthrene showed a bright orange colour in the early-exponential phase, which subsided during the late-exponential and stationary phases. TLC analysis of the early-exponential phase spent medium showed a single spot, which was identified as 1-H2NA based on its $R_{\mathrm{f}}(0.93)$ and UV-fluorescence properties (Table 1). Other metabolites could not be detected even in the mid-exponential, late-exponential and stationary phases of growth. This could be due to very low concentrations or absence of these metabolites in the spent medium. Phenanthrene-grown cells showed: (i) biotransformation of 1-H2NA to 2-carboxybenzaldehyde $\left(R_{\mathrm{f}} 0.90\right)$ and of 2-carboxybenzaldehyde to phthalic acid $\left(R_{\mathrm{f}} 0.62\right)$ (Table 1); (ii) good $\mathrm{O}_{2}$ uptake on phenanthrene and 1H2NA [5.5 and $3.9 \mathrm{nmol} \mathrm{O}_{2}$ consumed $\min ^{-1}$ (mg wet wt of cells $)^{-1}$, respectively], but no detectable $\mathrm{O}_{2}$ uptake with phthalic acid or protocatechuic acid (data not shown); (iii) presence of phthalic acid dioxygenase-oxygenase and -reductase components, 1-HNDO, 2-CBADH and protocatechuic acid 4,5-dioxygenase (P4,5DO) in the cell-free extract (Table 2); and (iv) enzymic conversion of 1-H2NA to phthalic acid $\left(R_{\mathrm{f}} 0.60\right)$ and of 2-carboxybenzaldehyde to phthalic acid $\left(R_{\mathrm{f}} 0.60\right.$, Table 1$)$. Time-dependent spectral changes in the protocatechuic acid dioxygenase reaction showed a decrease in the absorbance at $250 \mathrm{~nm}$ (disappearance of substrate, protocatechuic acid) with a concomitant increase at $410 \mathrm{~nm}$ (appearance of yellowcoloured product, 2-hydroxy-5-carboxymuconic semialdehyde), suggesting the meta ring-cleavage of protocatechuic acid by P4,5DO (data not shown). An enzyme activity versus growth profile showed maximum activity of 1$\mathrm{HNDO}$ at $9 \mathrm{~h}$ and of P4,5DO at $15 \mathrm{~h}$ of growth (data not shown). Cells grown on glucose showed neither oxygen uptake nor enzyme activities in the cell-free extract, indicating that the enzymes of the phenanthrene degradative pathways are inducible (Table 2).

\section{Purification of 1-HNDO from Pseudomonas sp. strain PPD}

The enzyme was very unstable in the cell-free extract and required $\mathrm{Fe}(\mathrm{II})(0.1 \mathrm{mM})$, DTT $(2 \mathrm{mM})$ and ethanol $(10 \%)$ for stability. Interestingly, the enzyme was stable at $60{ }^{\circ} \mathrm{C}$ for $5 \mathrm{~min}$ and showed prolonged stability for $20 \mathrm{~min}$ in the presence of $3-\mathrm{H} 2 \mathrm{NA}(1 \mathrm{mM})$. Kinetic analysis of partially purified enzyme revealed competitive inhibition with 3-H2NA (data not shown). 1-HNDO was purified by using heat treatment, 3-H2NA-affinity matrix and DEAE ion-exchange column chromatography to 12.5 fold, yield $4.2 \%$, with a specific activity of $61.5 \mu \mathrm{mol}$ 
Table 1. Detection of metabolites from the spent culture medium, whole-cell biotransformation and bulk enzyme reactions

\begin{tabular}{|c|c|c|c|c|}
\hline Sample & & $R_{\mathrm{f}}$ & $\begin{array}{l}\text { Fluorescence properties } \\
\qquad(254 \mathrm{~nm})\end{array}$ & Compound identified \\
\hline 1-H2NA & & 0.93 & $\begin{array}{l}\text { Fluorescent blue with quench } \\
\text { in centre }\end{array}$ & Standard \\
\hline 2-Carboxybenzaldehyde & & 0.90 & Black quench & Standard \\
\hline Phthalic acid & & 0.62 & Black quench & Standard \\
\hline Protocatechuic acid & & 0.77 & Dark blue quench & Standard \\
\hline \multicolumn{5}{|c|}{ Spent medium of culture grown on phenanthrene } \\
\hline & Spot 1 & 0.93 & $\begin{array}{l}\text { Fluorescent blue with quench } \\
\text { in centre }\end{array}$ & 1-H2NA \\
\hline \multicolumn{5}{|c|}{ Whole-cell biotransformation ${ }^{*}$ with: } \\
\hline \multirow[t]{2}{*}{ 1-H2NA } & Spot 1 & 0.93 & $\begin{array}{l}\text { Fluorescent blue with quench } \\
\text { in centre }\end{array}$ & $1-\mathrm{H} 2 \mathrm{NA}$ \\
\hline & Spot 2 & 0.90 & Black quench & 2-Carboxybenzaldehyde \\
\hline \multirow{2}{*}{ 2-Carboxybenzaldehyde } & Spot 1 & 0.90 & Black quench & 2-Carboxybenzaldehyde \\
\hline & Spot 2 & 0.62 & Black quench & Phthalic acid \\
\hline \multicolumn{5}{|c|}{ Bulk enzyme reaction $\dagger$ with: } \\
\hline $1-\mathrm{H} 2 \mathrm{NA}$ & Spot 1 & 0.60 & Black quench & Phthalic acid \\
\hline 2-Carboxybenzaldehyde & Spot 1 & 0.60 & Black quench & Phthalic acid \\
\hline
\end{tabular}

${ }^{*}$ Cells were grown on phenanthrene, harvested, and the biotransformation reaction was performed using 1-H2NA and 2-carboxybenzaldehyde as described in Methods.

$\dagger$ Cell-free extract was prepared from phenanthrene-grown cells; bulk enzyme reactions were performed with 1-H2NA and 2-carboxybenzaldehyde as described in Methods.

$\mathrm{min}^{-1} \mathrm{mg}^{-1}$ from PPD cells grown on phenanthrene (Table 3). SDS-PAGE showed a single band at a molecular mass of $39 \mathrm{kDa}$ (Fig. 2a). The enzyme was eluted as a single activity peak from Sephacryl S-200-HR gel filtration chromatography, with a native molecular mass of $160 \mathrm{kDa}$ (Fig. 2b). The enzyme showed activity in the $\mathrm{pH}$ range 6-9 with a maximum at $\mathrm{pH} 7.5$ (data not shown).

Table 2. Activities of enzymes involved in phenanthrene degradation by Pseudomonas strain PPD

\begin{tabular}{|lcc|}
\hline Enzyme & $\begin{array}{r}\text { Specific activity [nmol min } \\
(\mathbf{m g} \text { protein })^{-1} \text { ] from cells } \\
\text { grown on }\end{array}$ \\
\cline { 2 - 3 } & \multicolumn{2}{c|}{$\begin{array}{c}\text { Phenanthrene } \\
\text { Glucose }\end{array}$} \\
\hline 1-HNDO & 4640 & - \\
2-CBADH & 95 & - \\
Phthalic acid dioxygenase, & 20 & - \\
oxygenase & & - \\
Phthalic acid dioxygenase, & 499 & - \\
reductase & & 17 \\
P4,5DO & 1095 & - \\
Catechol 2,3-dioxygenase & 14 & \\
Catechol 1,2-dioxygenase & 14 & \\
GDO & 8.6 & \\
\hline
\end{tabular}

-, Activity could not be detected.

\section{Effect of metal chelators and metal ions}

The metal chelators EGTA and EDTA $(1 \mathrm{mM})$ inactivated $1-\mathrm{HNDO}$ by $30-40 \%$, while phenanthroline and $2,2^{\prime}-$ dipyridyl $(1 \mathrm{mM})$ inactivated it completely. Phenanthroline-inactivated enzyme regained $100 \%$ activity following addition of $\mathrm{Fe}(\mathrm{II})(1 \mathrm{mM})$. Other divalent metal ions $\left(\mathrm{Zn}^{2+}, \mathrm{Mg}^{2+}, \mathrm{Mn}^{2+}, \mathrm{Ca}^{2+}\right.$ and $\mathrm{Cu}^{2+}$ ) failed to reactivate the enzyme (data not shown).

\section{Identification of the reaction product of 1-HNDO}

To identify the product, large-scale enzyme reactions were performed under aerobic and anaerobic conditions (for $4 \mathrm{~h}$ ) using Thunberg tubes. Under aerobic conditions, a major spot with $R_{\mathrm{f}} 0.28$ (blue quench) was detected on TLC. After removing the enzyme by Centricon filtration (10 kDa, Pall Life Sciences), the filtrate gave an absorption maximum at $300 \mathrm{~nm}$ at $\mathrm{pH} \mathrm{7}$, and at 276 and $282 \mathrm{~nm}$ at pH 2 (Fig. 3), similar to that observed for 2-carboxybenzalpyruvic acid (Adachi et al., 1999; Barnsley, 1983). Under anaerobic conditions, a single spot with $R_{\mathrm{f}} 0.95$ corresponding to the substrate, 1-H2NA, was observed.

\section{Stoichiometry of the reaction}

Purified 1-HNDO showed a specific activity of $36.8 \mu \mathrm{mol}$ product formed $\mathrm{min}^{-1} \mathrm{mg}^{-1}$ by spectrophotometry and $34.4 \mu \mathrm{mol} \mathrm{O}_{2}$ consumed $\mathrm{min}^{-1} \mathrm{mg}^{-1}$ by oxygraph. The ratio of $\mathrm{O}_{2}$ consumed to product formed was 0.93 , suggesting that $\sim 1 \mathrm{~mol} \mathrm{O}_{2}$ is consumed to yield $1 \mathrm{~mol} 2$ - 
Table 3. Purification of 1-HNDO from Pseudomonas sp. strain PPD

\begin{tabular}{|c|c|c|c|c|c|c|}
\hline Step & Total vol. (ml) & $\begin{array}{c}\text { Total protein } \\
(\mathbf{m g})\end{array}$ & Total activity ${ }^{\star}$ & Sp. act. $\dagger$ & $\begin{array}{c}\text { Purification } \\
\text { (fold) }\end{array}$ & Yield (\%) \\
\hline Cell-free extract & 8.5 & 134 & 660 & 4.9 & 1 & 100 \\
\hline Dialysis I & 5.8 & 40.7 & 619 & 15.2 & 3.1 & 94 \\
\hline 3-H2NA-affinity chromatography & 60.5 & 4.11 & 218 & 53 & 11 & 33 \\
\hline Anion-exchange chromatography & 13 & 0.52 & 15.2 & 29 & 6 & 2.3 \\
\hline
\end{tabular}

${ }^{*} \mu \mathrm{mol} \min ^{-1}$.

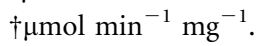

carboxybenzalpyruvic acid. This observation, along with the product identification data, suggests that the enzyme requires oxygen.

\section{Substrate specificity}

The enzyme showed activity with 1-H2NA but failed to show activity (spectral changes or $\mathrm{O}_{2}$ uptake) with gentisic acid, salicylic acid, 3-hydroxybenzoic acid, 4-hydroxybenzoic acid, 1-naphthol, 2-naphthol, 1-naphthoic acid, 2naphthoic acid, 2-H1NA, 3-H2NA or 6-H2NA (data not shown).

\section{Kinetic constants}

Initial reaction velocities were measured spectrophotometrically by varying the concentrations of 1-H2NA (1$200 \mu \mathrm{M})$. A representative substrate saturation plot for 1$\mathrm{H} 2 \mathrm{NA}$ is depicted in Fig. 4. Increasing the concentration of $1-\mathrm{H} 2 \mathrm{NA}$ led to linear increases in the activity up to $25 \mu \mathrm{M}$. With a further increase to 100 and $200 \mu \mathrm{M}$ there was a 15 and $45 \%$ decrease in activity, respectively, indicating substrate inhibition. A double reciprocal plot gave a $K_{\mathrm{i}}$ of $116 \pm 28 \mu \mathrm{M}$, a $K_{\mathrm{m}}$ of $13.5 \pm 3.2 \mu \mathrm{M}$ and a $V_{\max }$ of $114 \pm 20$ $\mu \mathrm{mol} \min ^{-1} \mathrm{mg}^{-1}$ for the substrate $1-\mathrm{H} 2 \mathrm{NA}$. The $k_{\text {cat }}$ and $k_{\text {cat }} / K_{\mathrm{m}}$ values were determined to be $70.4 \mathrm{~s}^{-1}$ and $520 \times 10^{4} \mathrm{~s}^{-1} \mathrm{M}^{-1}$. Of the compounds tested, 3-H2NA showed competitive inhibition with a $K_{\mathrm{i}}$ of $24 \pm 3.4 \mu \mathrm{M}$, and 2-H1NA showed a mixed-partial inhibition pattern with a $K_{\mathrm{i}}$ of $26 \pm 5 \mu \mathrm{M}$. Salicylic acid, gentisic acid, 3hydroxybenzoic acid, 4-hydroxybenzoic acid, 1-naphthol, 2-naphthol, 1-naphthoic acid and 2-naphthoic acid did not inhibit the activity of the enzyme (data not shown).

\section{DISCUSSION}

Pseudomonas sp. strain PPD can utilize phenanthrene, hydroxybenzoic acids ( $o-, m$ - and $p$-) and phthalic acid isomers $(o-, m$ - and $p-)$ as the sole source of carbon and energy (Deveryshetty et al., 2007; Vamsee-Krishna et al., 2006). Detection of 1-H2NA in the spent medium, wholecell respiration on phenanthrene and 1-H2NA, and activity of 1-HNDO, 2-CBADH, phthalic acid dioxygenase and $\mathrm{P} 4,5 \mathrm{DO}$ in the cell-free extract suggests that strain PPD degrades phenanthrene via the 'phthalic acid' route (Fig. 1; Tables 1 and 2). Low activity of phenanthrene-degrading enzymes in glucose-grown cells indicates that the enzymes are inducible (Table 2). Interestingly, strain PPD showed a carbon-source-dependent induction of two different ringcleaving protocatechuate dioxygenases. Phenanthrenegrown cells showed P4,5DO activity, whereas phthalic acid-grown cells showed protocatechuate 3,4-dioxygenase (P3,4DO) activity (Vamsee-Krishna et al., 2006). Phthalic acid-grown cells showed whole-cell $\mathrm{O}_{2}$ uptake on phthalic acid and protocatechuic acid (Vamsee-Krishna et al., 2006), indicating the induction of phthalic acid permease when grown on phthalic acid only. Phenanthrene-grown cells failed to show $\mathrm{O}_{2}$ uptake with phthalic acid, although it is one of the proposed intermediate metabolites. This could be due to the inability of phenanthrene or intracellular phthalic acid to induce phthalic acid permease, which is responsible for phthalic acid uptake (Chang \& Zylstra, 1999; Vamsee-Krishna \& Phale, 2008).

1-HNDO (EC 1.13.11.38) catalyses the conversion of 1H2NA to 2-carboxybenzalpyruvic acid. 1-HNDO was highly unstable, requiring $\mathrm{Fe}(\mathrm{II})$, DTT, ethanol and 3$\mathrm{H} 2 \mathrm{NA}$ as stabilizers; it showed heat stability for $20 \mathrm{~min}$ at $60{ }^{\circ} \mathrm{C}$ (Table 4). Using heat treatment, 3-H2NA-affinity chromatography and ion-exchange chromatography, 1HNDO was purified to homogeneity. The subunit molecular mass of the enzyme was determined to be $39 \mathrm{kDa}$ and the native molecular mass to be $160 \mathrm{kDa}$, indicating that the enzyme is a homotetramer (Fig. 3). 1HNDO from Nocardioides sp. strain KP7 was found to be a homohexamer with native molecular mass $270 \mathrm{kDa}$ and subunit molecular mass $45 \mathrm{kDa}$ (Iwabuchi \& Harayama, 1998; Table 4). pH-dependent changes in the spectral properties of the product of 1-HNDO were similar to those reported earlier, confirming the product to be 2-carboxybenzalpyruvic acid (Adachi et al., 1999; Barnsley, 1983). Identification of 2-carboxybenzalpyruvic acid under aerobic conditions, consumption of $1 \mathrm{~mol} \mathrm{O}_{2}$ per $1 \mathrm{~mol}$ of product formed and the requirement for $\mathrm{Fe}(\mathrm{II})$ suggest that $1-\mathrm{HNDO}$ is an extradiol-type ring-cleaving dioxygenase. 
(a)

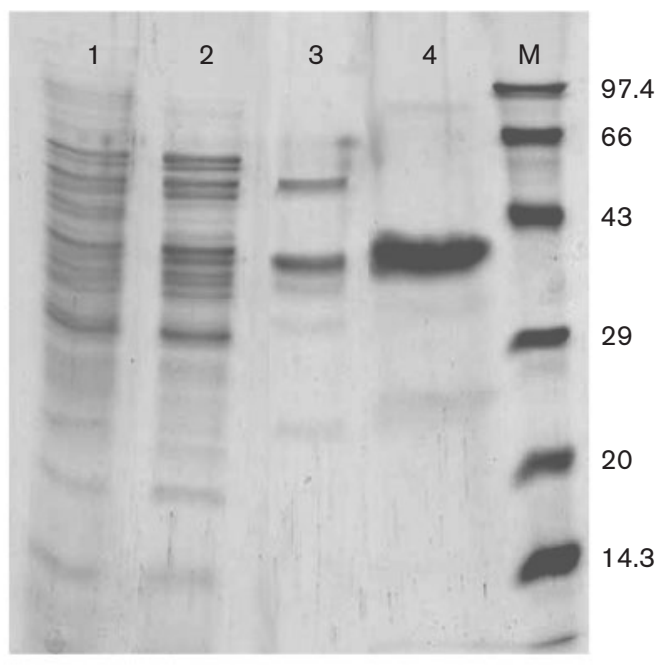

(b)

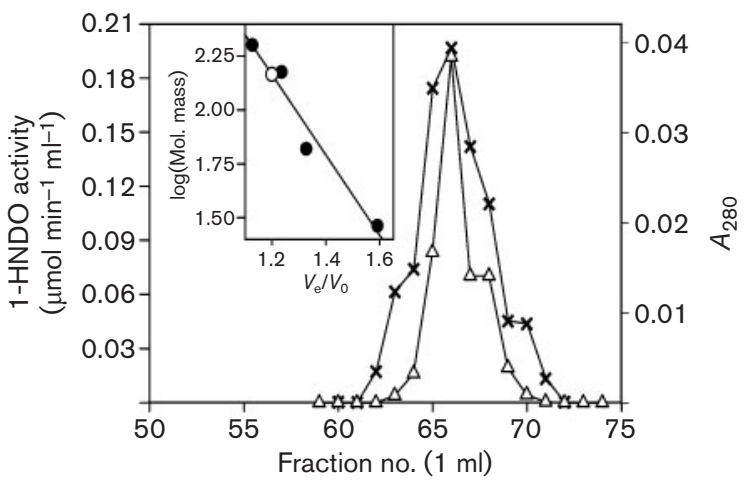

Fig. 2. Purification of 1-HNDO: (a) SDS-PAGE analysis during the different stages of purification. Lanes (each contains $5 \mu \mathrm{g}$ protein): 1 , cell-free extract; 2 , heat-treated fraction; 3, 3-H2NA affinity-purified pool; 4, DEAE eluted pool. $M$, molecular mass markers (kDa): phosphorylase $b$ (97.4), BSA (66), ovalbumin (43), carbonic anhydrase (29), soy-bean trypsin inhibitor (20) and lysozyme (14.3). (b) Elution profile of 1-HNDO from a Sephacryl $\mathrm{S}-200-\mathrm{HR}$ gel-filtration column. The dioxygenase activity is represented by crosses and protein elution $\left(A_{280}\right)$ by open triangles. Inset: plot of log(molecular mass) versus $V_{\mathrm{e}} / V_{0}$ for molecular mass protein markers $[\beta$-amylase $(200(\mathrm{kDa})$, alcohol dehydrogenase (150), BSA (66), and carbonic anhydrase (29)], represented by filled circles; the open circle represents 1 -HNDO.

1-HNDO from strain PPD showed activity with 1-H2NA and failed to act on substrate analogues, indicating that the enzyme is specific and similar to that reported from Nocardioides sp. strain KP7 (Iwabuchi \& Harayama, 1998). Gentisic acid 1,2-dioxygenase (GDO), an extradiol-type dioxygenase, has been shown to act on halogenated and alkylated derivatives of gentisic acid but not on salicylic acid or 1-H2NA (Crawford et al., 1975; Feng et al., 1999; Harpel \& Lipscomb, 1990; Werwath et al., 1998). Salicylic acid 1,2-dioxygenase (SDO) from Pseudoaminobacter

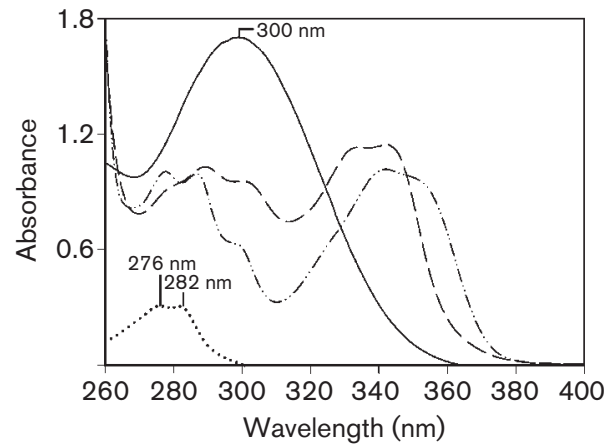

Fig. 3. UV-visible absorption spectra for the enzyme reaction product (2-carboxybenzalpyruvate) at $\mathrm{pH} 7.0$ (solid line) and at $\mathrm{pH} 2.0$ (dotted line), and for the substrate (1-H2NA) at $\mathrm{pH} 7$ (dashed line) and at $\mathrm{pH} 2.0$ (dash-dot-dash line) in phosphate buffer (50 mM).

salicylatoxidans showed activity on derivatives of salicylic acid, gentisic acid and 1-H2NA (Hintner et al., 2001, 2004). Based on the structure of GDO and SDO, it was proposed that the $\mathrm{N}$-terminal residues, which contribute to the active site, may be responsible for the wide substrate specificity of SDO (Matera et al., 2008). 1-HNDO from strain PPD showed competitive inhibition with 3-H2NA. This may be due to the presence of a carboxyl group at the 2 position on $1-\mathrm{H} 2 \mathrm{NA}$ and $3-\mathrm{H} 2 \mathrm{NA}$. With respect to substrate specificity, affinity constants and competitive inhibition, the 1-HNDOs from Pseudomonas strain PPD and Nocardioides sp. strain KP7 are similar (Table 4). However, interestingly, the enzyme from strain PPD showed substrate inhibition at a higher concentration, with a $K_{\mathrm{i}}$ of $116 \mu \mathrm{M}$. This feature does not appear to have

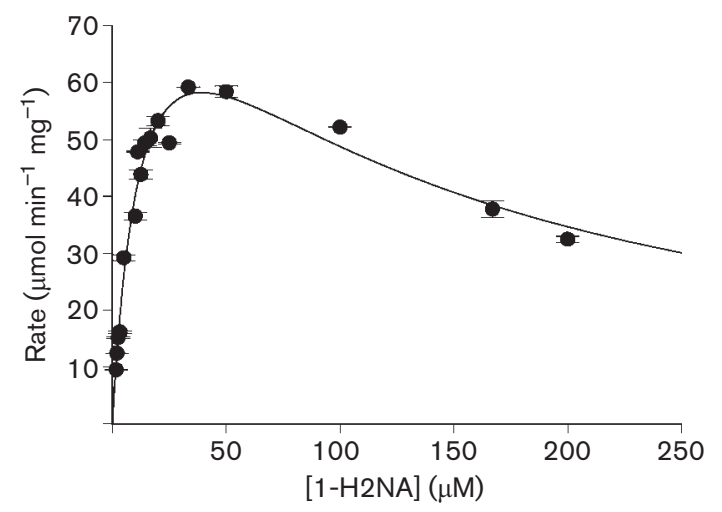

Fig. 4. Reaction velocity $(v)$ versus substrate concentration $[S]$ plot for 1-HNDO. The reactions were performed with $0.5 \mu \mathrm{g}$ enzyme, and with various concentrations of 1-H2NA from 1 to $200 \mu \mathrm{M}$. The graph was fitted using the model for substrate inhibition (noncompetitive) with the following equation: $v=\left\{V_{\max }\right\rfloor$ $\left.\left[1+\left(K_{\mathrm{m}} / S\right)+\left(S / K_{\mathrm{i}}\right)\right]\right\}$. 
Table 4. Comparison of properties of extradiol-type ring-cleaving dioxygenases from various bacteria

Derived from the available data in the respective references.

\begin{tabular}{|c|c|c|c|c|c|c|c|c|c|c|}
\hline Enzyme & Organism & $\begin{array}{c}\text { Subunit } \\
\text { mol. mass } \\
(\mathrm{kDa})\end{array}$ & $\begin{array}{c}\text { Native } \\
\text { mol. mass } \\
(\mathrm{kDa})\end{array}$ & $\begin{array}{c}\text { Heat } \\
\text { stability } \\
\left({ }^{\circ} \mathrm{C}\right)\end{array}$ & $\begin{array}{c}K_{\mathrm{m}} \\
(\mu \mathrm{M})\end{array}$ & $\begin{array}{c}k_{\mathrm{cat}} / K_{\mathrm{m}} \\
\left(\mathrm{s}^{-1} \mathrm{M}^{-1}\right)^{\star}\end{array}$ & $\begin{array}{l}\text { Active sites } \\
\text { per monomer }\end{array}$ & $\begin{array}{l}\mathrm{AA} \text { at } \mathrm{Fe}(\mathrm{II})- \\
\text { binding site }\end{array}$ & Structure & Reference \\
\hline \multirow[t]{7}{*}{ GDO } & Comamonas testosteroni & 41 & 158 & 60 & 85 & $4.3 \times 10^{6}$ & ND & $\mathrm{ND}$ & ND & Harpel \& Lipscomb (1990) \\
\hline & Comamonas acidovorans & $37-40$ & 164 & 60 & 74 & $4.3 \times 10^{6}$ & ND & ND & ND & Harpel \& Lipscomb (1990) \\
\hline & Pseudomonas alcaligenes $\mathrm{P} 25 \mathrm{X}$ & 39 & 154 & 60 & 92 & $0.44 \times 10^{6}$ & ND & ND & ND & Feng et al. (1999) \\
\hline & Pseudomonas putida $\mathrm{P} 35 \mathrm{X}$ & 41 & 82 & 60 & 143 & $0.4 \times 10^{6}$ & ND & ND & ND & Feng et al. (1999) \\
\hline & Moraxella osloensis OA3 & 40 & 154 & 60 & 7.1 & ND & $\mathrm{ND}$ & $\mathrm{ND}$ & $\mathrm{ND}$ & Crawford et al. (1975) \\
\hline & Sphingomonas sp. strain RW5 & 38.5 & 177 & ND & 15 & $5.1 \times 10^{6}$ & ND & ND & ND & Werwath et al. (1998) \\
\hline & Escherichia coli $\mathrm{O} 157: \mathrm{H} 7$ & 38.9 & 154 & $\mathrm{ND}$ & 11 & $384 \times 10^{6}$ & 1 & $\begin{array}{c}\mathrm{H} 104, \mathrm{H} 106 \text { and } \\
\mathrm{H} 145\end{array}$ & 2.4 & Adams et al. (2006) \\
\hline $\mathrm{HGO} \dagger$ & Pseudomonas fluorescens & 38 & ND & $\mathrm{ND}$ & 600 & ND & $\mathrm{ND}$ & $\mathrm{ND}$ & ND & Adachi et al. (1966) \\
\hline SDO & Pseudoaminobacter salicylatoxidans & 45 & 180 & $\mathrm{ND}$ & 12 & $0.2 \times 10^{6}$ & 1 & $\begin{array}{c}\text { H119, H121 and } \\
\text { H160 }\end{array}$ & 2.9 & $\begin{array}{l}\text { Hintner et al. }(2001,2004) \text {; } \\
\text { Matera et al. }(2008)\end{array}$ \\
\hline \multirow[t]{2}{*}{ 1-HNDO } & Nocardioides sp. strain KP7 & 45 & 270 & ND & 10 & $11.4 \times 10^{6}$ & ND & ND & ND & Iwabuchi \& Harayama (1998) \\
\hline & Pseudomonas sp. strain PPD & 39 & 148 & 60 & 13.5 & $5.2 \times 10^{6}$ & ND & ND & ND & Present study \\
\hline
\end{tabular}

ND, Not determined.

${ }^{*}$ Some of the $k_{\mathrm{cat}} / K_{\mathrm{m}}$ values were derived from the available data in the respective references.

$\dagger$ Homogentisate oxygenase. 
been reported so far for any of the ring-cleaving dioxygenases belonging to this group (Table 4).

The substrate specificity, involvement of $\mathrm{Fe}(\mathrm{II})$, position of ring-cleavage and product formed indicate that the catalytic mechanism of 1-HNDO is probably similar to that of GDO. Further characterization, such as determination of the active-site amino acids, reaction mechanism and comparative analysis, may help in engineering these enzymes for wide substrate acceptance and improved catalytic constants for efficient bioremediation.

\section{ACKNOWLEDGEMENTS}

A research grant to P.S.P. from BRNS, Govt. of India and a senior research fellowship to D. J. from UGC, Govt of India, is gratefully acknowledged.

\section{REFERENCES}

Adachi, K., Iwayama, Y., Taniok, H. \& Takeda, Y. (1966). Purification and properties of homogentisate oxygenase from Pseudomonas fluorescens. Biochim Biophys Acta 118, 88-97.

Adachi, K., Iwabuchi, T., Sano, H. \& Harayama, S. (1999). Structure of the ring cleavage product of 1-hydroxy-2-naphthoate, an intermediate of the phenanthrene-degradative pathway of Nocardioides sp. strain KP7. J Bacteriol 181, 757-763.

Adams, M. A., Singh, V. K., Keller, B. O. \& Jia, Z. (2006). Structural and biochemical characterization of gentisate 1,2-dioxygenase from Escherichia coli O157: H7. Mol Microbiol 61, 1469-1484.

Arciero, D. M. \& Lipscomb, J. D. (1986). Binding a ${ }^{17} \mathrm{O}$-labeled substrate and inhibitors to protocatechuate 4,5-dioxygenase nitrosyl complex: evidence for direct substrate binding to the active site $\mathrm{Fe}^{2+}$ of extradiol dioxygenases. J Biol Chem 261, 2170-2178.

Barnsley, E. A. (1983). Phthalate pathway of phenanthrene metabolism: formation of 2' -carboxybenzalpyruvate. J Bacteriol 154, 113-117.

Bradford, M. M. (1976). A rapid and sensitive method for the quantitation of microgram quantities of protein utilizing the principle of protein-dye binding. Anal Biochem 72, 248-254.

Bucker, M., Glatt, H. R., Platt, K. L., Avnir, D., Ittah, Y., Blum, J. \& Oesch, F. (1979). Mutagenicity of phenanthrene and phenanthrene K-region derivatives. Mutat Res 66, 337-348.

Chang, H. K. \& Zylstra, G. J. (1999). Characterization of the phthalate permease OphD from Burkholderia cepacia ATCC 17616. J Bacteriol 181, 6197-6199.

Crawford, R. L., Hutton, S. W. \& Chapman, P. J. (1975). Purification and properties of gentisate 1,2-dioxygenase from Moraxella osloensis. J Bacteriol 121, 794-799.

Davis, M. I., Orville, A. M., Neese, F., Zaleski, J. M., Lipscomb, J. D. \& Solomon, E. I. (2002). Spectroscopic and electronic structure studies of protocatechuate 3,4-dioxygenase: nature of tyrosinate-Fe(III) bonds and their contribution to reactivity. J Am Chem Soc 124, 602-614.

Deveryshetty, J., Suvekbala, V., Varadamshetty, G. \& Phale, P. S. (2007). Metabolism of 2-, 3- and 4-hydroxybenzoates by soil isolates Alcaligenes sp. strain PPH and Pseudomonas sp. strain PPD. FEMS Microbiol Lett 268, 59-66.

Doddamani, H. P. \& Ninnekar, H. Z. (2000). Biodegradation of phenanthrene by a Bacillus species. Curr Microbiol 41, 11-14.
Evans, W. C., Fernley, H. N. \& Griffiths, E. (1965). Oxidative metabolism of phenanthrene and anthracene by soil pseudomonads. The ring-fission mechanism. Biochem J 95, 819-831.

Feng, Y., Khoo, H. E. \& Poh, C. L. (1999). Purification and characterization of gentisate 1,2-dioxygenases from Pseudomonas alcaligenes NCIB 9867 and Pseudomonas putida NCIB 9869. Appl Environ Microbiol 65, 946-950.

Ghosh, D. K. \& Mishra, A. K. (1983). Oxidation of phenanthrene by a strain of Micrococcus: evidence of protocatechuate pathway. Curr Microbiol 9, 219-224.

Harpel, M. R. \& Lipscomb, J. D. (1990). Gentisate 1,2-dioxygenase from Pseudomonas. Purification, characterization, and comparison of the enzymes from Pseudomonas testosteroni and Pseudomonas acidovorans. J Biol Chem 265, 6301-6311.

Hayaishi, O. \& Hoshimoto, K. (1950). Pyrocatecase, a new enzyme catalyzing oxidative breakdown of pyrocatechin. J Biochem 37, 371-374.

Hintner, J. P., Lechner, C., Riegert, U., Kuhm, A. E., Storm, T., Reemtsma, T. \& Stolz, A. (2001). Direct ring fission of salicylate by a salicylate 1,2-dioxygenase activity from Pseudaminobacter salicylatoxidans. J Bacteriol 183, 6936-6942.

Hintner, J. P., Reemtsma, T. \& Stolz, A. (2004). Biochemical and molecular characterization of a ring fission dioxygenase with the ability to oxidize (substituted) salicylate(s) from Pseudaminobacter salicylatoxidans. J Biol Chem 279, 37250-37260.

Iwabuchi, T. \& Harayama, S. (1997). Biochemical and genetic characterization of 2-carboxybenzaldehyde dehydrogenase, an enzyme involved in phenanthrene degradation by Nocardioides sp. strain KP7. J Bacteriol 179, 6488-6494.

Iwabuchi, T. \& Harayama, S. (1998). Biochemical and molecular characterization of 1-hydroxy-2-naphthoate dioxygenase from Nocardioides sp. KP7. J Biol Chem 273, 8332-8336.

Kita, A., Kita, S., Fujisawa, I., Inaka, K., Ishida, T., Horiike, K., Nozaki, M. \& Miki, K. (1999). An archetypical extradiol-cleaving catecholic dioxygenase: the crystal structure of catechol 2,3-dioxygenase (metapyrocatechase) from Pseudomonas putida mt-2. Structure 7, 25-34.

Kiyohara, H., Nagao, K. \& Nomi, R. (1976). Degradation of phenanthrene through o-phthalate by an Aeromonas sp. Agric Biol Chem 40, 1075-1082.

Kojima, Y., Itada, N. \& Hayaishi, O. (1961). Metapyrocatachase: a new catechol-cleaving enzyme. J Biol Chem 236, 2223-2228.

Laemmli, U. K. (1970). Cleavage of structural proteins during the assembly of the head of bacteriophage T4. Nature 227, 680-685.

March, S. C., Parikh, I. \& Cuatrecasas, P. (1974). A simplified method for cyanogen bromide activation of agarose for affinity chromatography. Anal Biochem 60, 149-152.

Mastrangelo, G., Fadda, E. \& Marzia, V. (1996). Polycyclic aromatic hydrocarbons and cancer in man. Environ Health Perspect 104, 1166 1170 .

Matera, I., Ferraroni, M., Burger, S., Scozzafava, A., Stolz, A. \& Briganti, F. (2008). Salicylate 1,2-dioxygenase from Pseudaminobacter salicylatoxidans: crystal structure of a peculiar ring-cleaving dioxygenase. J Mol Biol 380, 856-868.

Ono, K., Nozaki, M. \& Hayaishi, O. (1970). Purification and some properties of protocatechuate 4,5-dioxygenase. Biochim Biophys Acta 220, 224-238.

Phale, P. S., Basu, A., Majhi, P. D., Deveryshetty, J., Vamsee-Krishna, C. \& Shrivastava, R. (2007). Metabolic diversity in bacterial degradation of aromatic compounds. OMICS 11, 252-279.

Prabhu, Y. \& Phale, P. S. (2003). Biodegradation of phenanthrene by Pseudomonas sp. strain PP2: novel metabolic pathway, role of 
biosurfactant and cell surface hydrophobicity in hydrocarbon assimilation. Appl Microbiol Biotechnol 61, 342-351.

Samanta, S. K., Chakraborti, A. K. \& Jain, R. K. (1999). Degradation of phenanthrene by different bacteria: evidence for novel transformation sequences involving the formation of 1-naphthol. Appl Microbiol Biotechnol 53, 98-107.

Shu, L., Chiou, Y. M., Orville, A. M., Miller, M. A., Lipscomb, J. D. \& Que, L., Jr (1995). X-ray absorption spectroscopic studies of the Fe(II) active site of catechol 2,3-dioxygenase. Implications for the extradiol cleavage mechanism. Biochemistry 34, 6649-6659.

Stanier, R. Y. \& Ingraham, J. L. (1954). Protocatechuic acid oxidase. J Biol Chem 210, 799-808.

Sugumaran, M. \& Vaidyanathan, C. S. (1978). Affinity chromatography of homogentisate 1,2-dioxygenase from Aspegillus niger. FEMS Microbiol Lett 4, 343-347.

Vamsee-Krishna, C. \& Phale, P. S. (2008). Bacterial degradation of phthalate isomers and their esters. Indian J Microbiol 48, 19-34.
Vamsee-Krishna, C., Mohan, Y. \& Phale, P. S. (2006). Biodegradation of phthalate isomers by Pseudomonas aeruginosa PP4, Pseudomonas sp. PPD and Acinetobacter lwoffii ISP4. Appl Microbiol Biotechnol 72, 1263-1269.

Vetting, M. W. \& Ohlendorf, D. H. (2000). The $1.8 \AA$ crystal structure of catechol 1,2-dioxygenase reveals a novel hydrophobic helical zipper as a subunit linker. Structure 8, 429-440.

Vetting, M. W., D’Argenio, D. A., Ornston, L. N. \& Ohlendorf, D. H. (2000). Structure of Acinetobacter strain ADP1 protocatechuate 3, 4dioxygenase at $2.2 \AA$ resolution: implications for the mechanism of an intradiol dioxygenase. Biochemistry 39, 7943-7955.

Werwath, J., Arfmann, H. A., Pieper, D. H., Timmis, K. N. \& Wittich, R. M. (1998). Biochemical and genetic characterization of a gentisate 1,2dioxygenase from Sphingomonas sp. strain RW5. J Bacteriol 180, 41714176.

Edited by: H. L. Drake 